Technological University Dublin

ARROW@TU Dublin

2010-01-01

\title{
Through the Lens of A "Branded Criminal": the Politics of Marginal Cinema in India
}

\author{
Rashmi Sawhney \\ Technological University Dublin, rashmi.sawhney@gmail.com
}

Follow this and additional works at: https://arrow.tudublin.ie/aaschmedbk

Part of the Film and Media Studies Commons

\section{Recommended Citation}

Sawhney, R. (2010) 'Through the Lens of A "Branded Criminal": the Politics of Marginal Cinema in India' in South Asian Media Cultures: Audiences, Reception, Contexts (Ed. Banaji). London: Anthem Press, pp.

201-20.

This Book Chapter is brought to you for free and open access by the School of Media at ARROW@TU Dublin. It has been accepted for inclusion in Books/Book chapters by an authorized administrator of ARROW@TU Dublin.

For more information, please contact

arrow.admin@tudublin.ie, aisling.coyne@tudublin.ie, gerard.connolly@tudublin.ie.

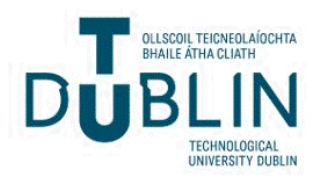




\section{Through the Lens of a 'Branded Criminal': The Politics of Marginal Cinema in India'}

\section{Dr. Rashmi Sawhney}

What I'm about to narrate is the story of the Chharas, one of the communities that constitutes the sixty million 'denotified and nomadic peoples' (DNTs) ${ }^{2}$ in India. This is not though, a 'story of the Chharas' in either a mythical or a historical sense, better described as an aerial shot of the media-channelled ripples effecting change in the lived conditions of the Chharas. It is centripetal to the extent that the loci of the narrative is grounded in the agency, cultural production and activism springing out of Chharanagar, a 'ghetto of Chhara DNTs'3 in Ahmedabad, Gujarat. One must also, it seems, locate the writing of this chapter itself in the context of these mediated socio-cultural ripples and acknowledge the crass limitations of cultural theory as a guide, even an accomplice, to social activism. As Stuart Hall said, speaking on the subject of AIDS in the 1990s, 'against the urgency of people dying in the streets, what in God's name is the point of cultural studies?', adding that, at the same time, 'AIDS raises politically important cultural questions too - who gets represented and who does not - that cultural studies alone has a privileged capacity to address' (Procter, 2004:2). From this vantage point, this chapter explores the politics of Chhara cinema, deconstructing its production process, form and audience, in seeking to locate marginal cinemas within the larger discursive context of Indian media cultures. The argument developed is that in order to account for doubly marginalised cinema cultures operating in the space of a 'fourth' or 'indigenous' cinema, received theories of audience, genre and form need to transcend the fixity imposed by the 'national' framework and start engaging with the inherent openness and fluidity of film as text and practice. The chapter is structured into three parts: the first part introduces the socio-historical context of the stigmatisation of the Chharas as criminals and their ongoing social activism through theatre and media production; part two focuses on Chhara film production, highlighting the politics of audience and cultural capital in the Indian film and media sphere; the final part is a discussion of Bulldozer (2006), emphasising the form and aesthetic of the film in offering a reading of Chhara cinema . 


\section{Chharas: History, Social Activism and Media Production}

The Chharas are originally a nomadic community from the Punjab region (same as the Sansis or Kanjars), and only one among about two-hundred such groups, whose nomadic lifestyles were systematically obliterated by the British government in the nineteenth century. ${ }^{4}$ British rationalism deeply shaped by the transition from feudalism to industrialism, both rooted in the value of land/capital ownership, failed to comprehend nomadism, resulting in reactionary measures, and the labelling of these communities as criminals by way of the 1871 Criminal Tribes Act. Such nomadic communities who were itinerant traders, craftsmen, or cattle-herders in pre-colonial times, had already been dealt a blow by the building of railway lines in the 1850 s and the passing of the Indian Forest Act in 1865.This deprived them of their access to the forests and its resources, and transferred it instead, into the hands of British-appointed forest officers. At least 70 tribal uprisings (across nomadic and settled communities) took place in colonial India, some of which have been documented through the work of the Subaltern Studies Collective; more recently, Ghanshyam Shah's (2004) substantial chapter on tribal movements indicates the preeminence of the tribal's place in the imagining and shaping of modern India.

The word 'tribal' conjures up images of forest-dwelling communities; industrialisation, mining, and dams ravaging traditional ways of life and sustenance ${ }^{5}$. These images have been beamed into living rooms through television screens time and again, and constitute a very real tribal world. However, these imageries exclude those nomadic communities such as the Chharas, who were forcefully 'settled' in prison-like ghettos replete with high walls and barbed wire fences by the British in the 1930s, in what were largely urban areas. Such communities have, for the past 80 years or so, come to inhabit the neglected peripheries of modern Indian cities, embodying the complexities of a violent 'up-rooting' through resettlement, and a simultaneous denial of the civil rights of settled Indian citizens. The story 
changes little after independence: in a magnanimous gesture by India's first Prime Minister Jawaharlal Nehru, those communities notified as 'Criminal Tribes' during colonial rule were 'denotified' in 1952; no further attempt at rehabilitation accompanied this announcement, and in 1956 the Habitual Offenders Act was brought into force. The new Act did not decry the DNTs as 'born criminal', but retained many of the provisions of the previous Act in terms of restrictions on movement and incarceration in 'corrective settlements'. This fuelled and sustained public perception of DNTs as 'criminals'. Despite the efforts of social activists in India, strong campaigns run by Resist Initiative International (RII) and the Forum for Factfinding Documentation and Advocacy (FFDA), and appeals by the UN's Committee on Elimination of Racial Discrimination (CERD), the Habitual Offenders Act still remains to be repealed.

Irrespective of this 'radical past', to borrow the words of Nandini from Govind Nihalani's Hazaar Chaurasi ki Maa ('Mother of 1084', 1998, Hindi), which might 'seem fashionable', Chharanagar embodies in every sense, an ordinary and familiar setting of a lower-class urban sprawl in an up-coming metropolitan city. Narrow lanes, make-shift, halfbuilt houses and shops made with plaster, concrete, mud, and tin, line both sides of the streets, jostling for space, cheek-by-jowl, as is the case in many parts of urban India. Residents, traders, shopkeepers, women, go about their daily chores; children run across the streets, dodging bicycles, scooters and rickshaws with some agility; music from the latest Bombay commercial film blares through a loudspeaker hidden from sight. There is a sense of quietness here despite the frenetic movement and constant buzz. It may be the demands my mind makes on my imagination in the knowledge that I share an awareness of Chhara history, but one gets the feeling that a cry of lament engulfs the area into a still silence. Some twenty thousand residents live in this three square mile area that constitutes Chharanagar, which is infamous in Gujarat, a state where the consumption of alcohol is prohibited, for the illegal brewing of liquor. Many of the residents continue to live here since 'denotification' and release from the settlement, which has over the years, become 'home'. 


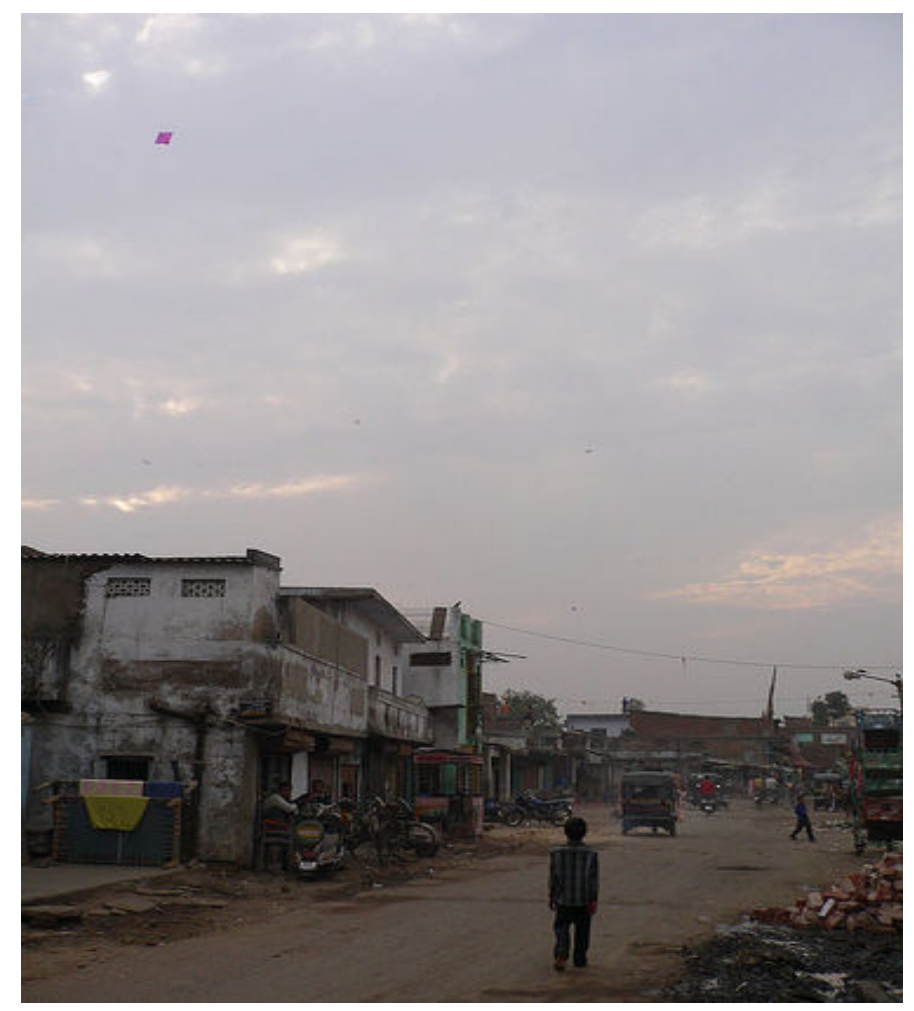

Figure 1. 'Entrance to Chharanagar' (Photo credit: P. Kerim Friedman)

In August 1998, a library and community centre was established in Chharanagar by the Indian writer and activist Mahasveta Devi, through the Bhasha Research and Publication Centre, Vadodara. Over time, these became focal points for the youth of Chharanagar to meet. Six months earlier, in February 1998, in another distant part of India in Purulia district of West Bengal, Budhan Sabar, a DNT man, had been killed through torture while in police custody, and the Kheria Sabar Welfare Samiti led by Mahasveta Devi had filed a petition seeking justice in the Calcutta High Court. The young boys and girls of Chharanagar decided to stage a play based on a published version of the court verdict delivered by Justice Ruma Paul of the Calcutta High Court ${ }^{6}$. To date, close to two hundred performances of this play have been staged across the country. This, effectively, marked the beginning of a wave of media-driven interventions by the Chharas, in some ways an expression of their politicisation. ${ }^{7}$ However, the Chharas' romance with theatre had begun in 1980, in a manner both symbolic and ironic: Prem Prakash, a well-known Gujarati theatre director was producing a play called 'Spartacus', and came to Chharanagar looking for actors to cast as 
'slaves'. An older generation of Chharas performed this play, which became a major success in the history of Gujarati stage productions, generating an interest in theatre in Chharanagar, later rekindled through the theatre group established in 1998.

To commemorate Budhan Sabar's tragic death and with the objective of speaking on behalf of the hundreds of others silenced like Budhan, the theatre group set up in Chharanagar was called 'Budhan Theatre' and over the last ten years, twenty-one different plays, including a recent adaptation of Jean Genet's 'Balcony', have dealt with issues of social injustice and stigmatisation faced by tribal communities on a daily basis. The tremendous potential for impact of these productions becomes apparent when Dakxin Bajrange, Chhara filmmaker and theatre director, proudly describes how the Chharas are now perceived as 'a community of actors' as opposed to 'a community of thieves'.

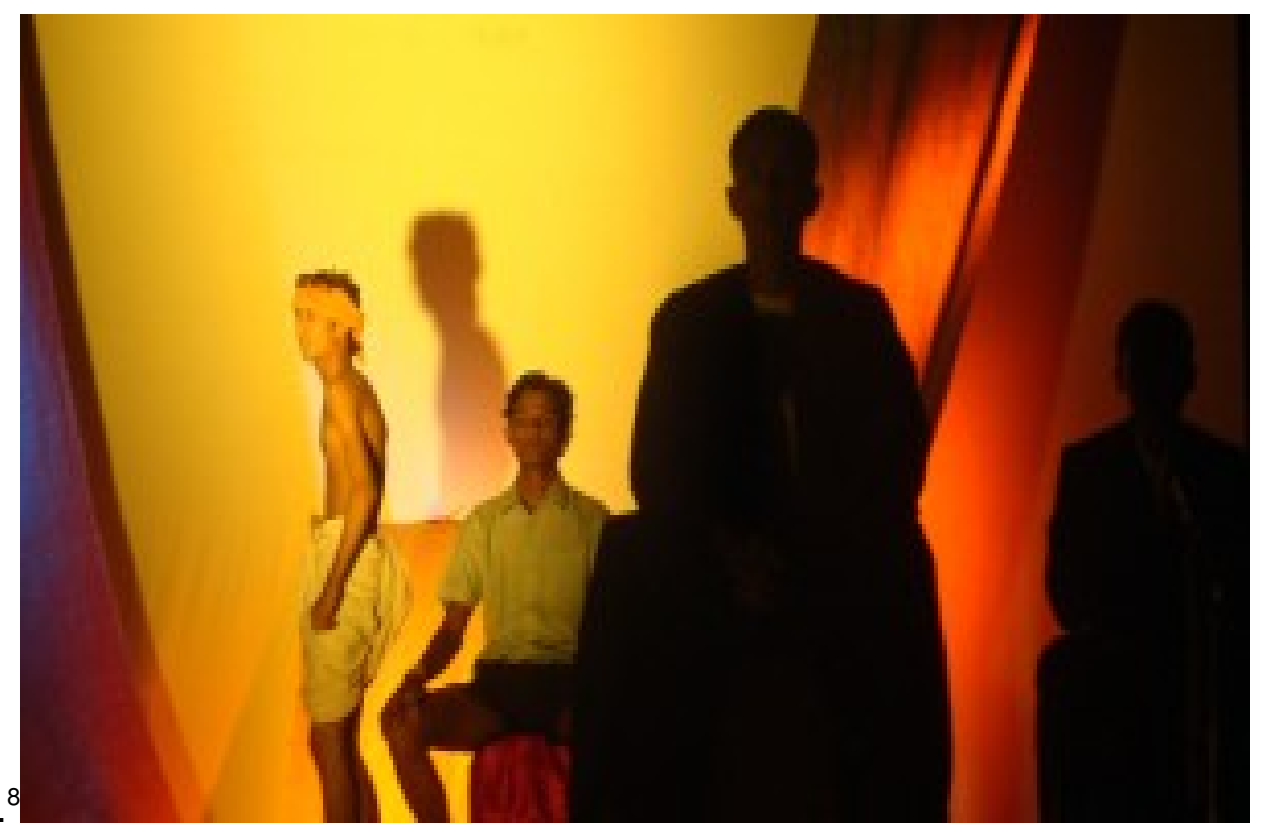

\section{Figure 2: Scene from EkAur Balcony ('One More Balcony’)}

Left to right: Atish Indrekar, Jitendra Indrekar, Sandeep Indrekar, Agnesh Indrekar 


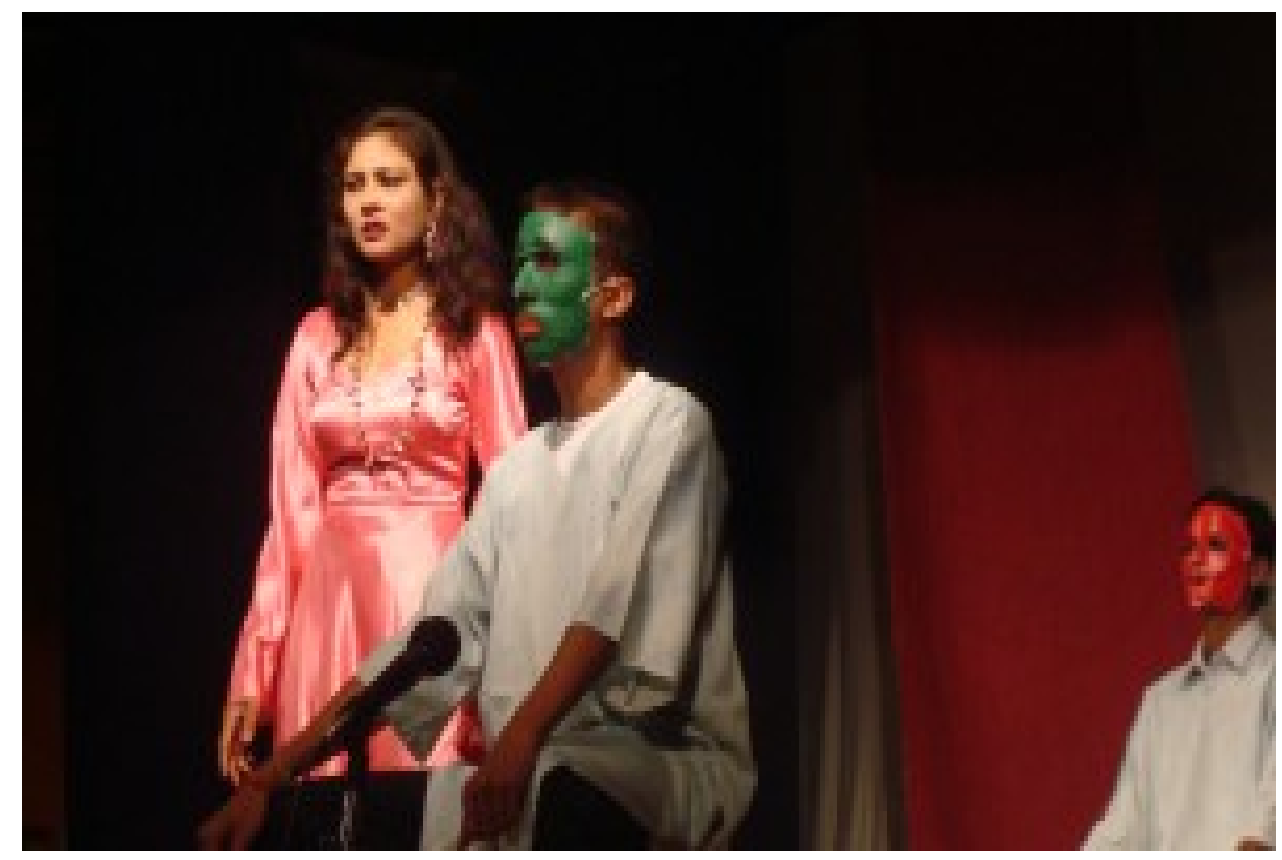

\section{Figure 3: Scene from EkAur Balcony ('One More Balcony')}

Left to right: Kalpana Gagdekar, Sandeep Indrekar, Jitendra Indrekar

The impact of these productions on mainstream Indian society is evident through the encouraging invitations Budhan Theatre has recieved in recent times to perform at premier locations in Ahmedabad such as Crosswords, HK Hall, City College, and the Indian Institute of Management. The plays have also attracted a good deal of media coverage across India, including in mainstream national newspapers like The Times of India and The Hindu, and magazines such as Tehelka. New Delhi Television (NDTV), a leading national media company, produced a special feature on Budhan Theatre in 2007. Moreover, as a site of creative struggle, Chharanagar has attracted national and international attention: in 2003, Delhi-based documentary filmmaker, Lalit Vachani, produced The Chhara Projects (video, $63 \mathrm{~min}$, rough cut) on the use of political street theatre; Kerim Friedman and Shashwati Talukdar, ethnographic documentary filmmakers based in Taiwan and the USA co-produced Acting Like A Thief (2005, DVD, 15 min, DER) which is part of a larger film project entitled Hooch and Hamlet in Chharanagar, currently in production. 
Despite such attention from both mainstream and independent media, Bajrange is firm in maintaining that if people really want to help the Chharas and other DNTs like us, they need to go beyond an appreciation of our plays and films and start giving us jobs in the companies they run, admissions in the educational institutes they teach in'. 9 To some extent, a few Chhara youth originally involved in the setting up of the Budhan Theatre Group have already secured jobs in mainstream media establishments. Kalpana Gagdekar has found a foothold in the commercial Gujarati film industry (which though floundering, is still recognised as an industry) and also acts in other theatre productions; Roxy Gagdekar works as a journalist and crime reporter for the newspaper DNA; Alok Gagdekar, who graduated from the National School of Drama (NSD) in Delhi works in the Bombay film industry and with Saathi, a Bombay-based NGO; Vivek Ghamande, who also graduated from the NSD too works in the Bombay film industry; Tushaar Kodekar works as a television reporter in a Gujarati channel called TV9 and hosts two popular crime shows - 'Finger Print' and 'Crime Diary'; Ankur Garange works with Tushaar in TV9 as a scriptwriter for the crime shows; and Dakxin Bajrange, who is at the helm of the Chhara's cultural production, is an independent documentary filmmaker and director in Gujarati film and television media. His independent documentaries include The Lost Water (2007), Bulldozer (2006), Actors are Born Here (2006), Fight for Survival (2005), Thought for Development (2005), and his theatrical credits as writer, director and actor include Budhan, Pinya Hari Kale Ki Maut, Encounter, Majhab Hameen SikhataAapas Mein Bair Rakhna, Bhoma, Khoj, Ulgulan, and Muje Mat Maro...Saab. He is currently working as associate director on a Gujarat film series with the acclaimed documentary filmmaker Rakesh Sharma. Despite their individual commitments, those Chharas still based in Ahmedabad, regularly train younger artists and media producers shaping a new generation of cultural activists, ensuring for them a creative voice and space and potentially a livelihood in the years to come. Notwithstanding this considerable success, Chharas are still refused bank loans, and as Sonia Faleiro writes, 'the back seat of the police van is a place every adult Chhara is acquainted with' (Tehelka, 2005). 
The picture painted above may lead one into thinking of Budhan Theatre as a representative voice for the Chharas and hence symbolic of the larger sentiment of 'progress' in Chharanagar. Rather, it represents a counter-voice, oppositional because its key rationale is to stop the tracks of history, to free the Chharas from the historical burden of being branded as criminals, and to nurture younger generations as artists, preventing the earlier complicity established between Chhara liqueur brewers, petty thieves and the police: 'we want a Chharanagar where words like thief and alcohol have no place. Where children don't know what these words mean' (Bajrange in Tehelka, 2005). ${ }^{10}$ Thus, the creative outputs of the Chharas need to be seen as embodying precisely the zone in and through which an older history of marginalisation and abuse of the Chhara people by the colonial government and the Indian state is being actively contested.

It is clear that the Chharas' use of media as a vehicle to carry their stories is rather unusually focussed, almost strategically so, one might suggest. In very few other tribal communities, whether denotified, nomadic or settled, does one encounter such extensive and single-minded emphasis on modern media as a way of addressing popular misperceptions. It could be argued, as Bajrange himself suggests in the film Acting Like A Thief (2005), that the Chharas have always had an acumen for the performative, and hence by extrapolation, theatre, cinema and television present a natural attraction. Indeed, the kind of media programming the Chhara youth are involved in certainly suggests a tendency towards the spectacular and folk dimensions of performance: crime-based shows on television, Gujarati commercial cinema, and a theatre group whose plays don't shy from melodrama, for example. Given the absolutely low production costs of Budhan Theatre plays, and considering that this is street theatre at its political best, the productions of the group rely extensively on strong, dramatic scripts, evocative body language, the optimum and creative use of space, and nominal props. To an extent, this already defines and restricts the form of the plays. 
It would be an interesting exercise to map the aesthetic characteristics of these plays in the context of wider street theatre or commercial theatre representing a more middle-class ethos; or to study the form and content of the television stories on crime, or the newspaper reports on crime, in relation to this kind of reportage originating from mainstream Indian society. However, I would like to focus here on the cinema, and to look more closely at the kinds of films emerging from Chharanagar, within the wider framework of debates on mainstream Indian cinema. The reasons for focusing on cinema, rather than a general 'media culture' demand some elaboration. Firstly, there is the obvious limitation of treating theatre, cinema, television, and print journalism as a single cross-platform media culture whereby the specificities of form and the production politics of each of these mediums would be compromised. Secondly, the aesthetic style evidenced in Chhara cinema references a wider history of Indian film and film-related discourses that can be drawn upon to signal the challenges to documentary filmmakers working from the margins. The production processes associated with the aesthetics of Chhara cinema also allows an interrogation of the place of this cinema within a larger Indian film culture - how can doubly marginalised films and filmmakers be accounted for in film theory? - a question taken up in section three of this chapter. And finally, the material quality of a DVD, a VCD, or a film print lends itself to constituting a mobile archive - accessible across time and space - for understanding the processes that shape historical narration, revisions, re-presentations, and indeed communal mobilisation through the media. Cinema thus, by virtue of being able to transgress spatiotemporal and cultural boundaries constitutes the most critical creative expression through which the Chharas can aspire to influence social perception.

\section{The Politics of Production: Genre, Audience and Cultural Capital}

\footnotetext{
'My sole intention in making films is to effect change. Where I or my theatre cannot reach, there my films should be able to reach. They should be able to sensitise the audience to the voices and issues of the most marginalised communities.'
}

(Dakxin Bajrange, Chhara theatre producer and filmmaker) 
The films produced by the Chharas are documentaries. Following on from John Grierson's use of the term 'documentary' for the first time in relation to Robert Flaherty's film Moana in 1936, the conventions that are assumed to generally characterise documentary films include a distinctive viewpoint and approach to form and production method, along with some sort of expectation in terms of an audience response (Ellis, 2005). Through interviews and a wider critical engagement with film theory, this section highlights some of the key challenges involved in the production of documentary film for the Chharas: a reading that could be extrapolated to represent the situation of other marginalised communities, particularly DNTs, in urban India. The Chhara films, mainly produced by Bajrange, are made from an advocacy point of view, with the objective, at the very minimum, to generate an awareness of the history of the Chharas and their everyday troubles. This indicates that form and audience are crucial to Chhara films; their objective would lie unrealised without an effective language of cinema or without spectators. This is true for any film and filmmaker, but what is crucial in the Chhara case is that cinema is much more than an artistic expression: it is a 'fight for survival'.

\section{$\underline{\text { Audiences }}$}

I begin with the issue of audiences, and this involves a necessary digression from the Chharas to debates within film studies. As it stands, the Chharas don't have any mechanism for distribution and exhibition of their films, other than an ad hoc 'handing out' of DVDs, free of cost, to anyone remotely interested in giving them a ear, and arguably an eye. Only recently have Documentary Educational Resources (DER) taken up distribution for The Lost Water. It may come as a surprise to some to learn that Indian audiences don't pay to watch documentaries, and hence, independent documentaries seldom get screened in cinema halls, or outside film festivals, film clubs and the university circuit. There are various reasons for this lack of interest in documentary (both among spectators and film theorists, whose 
focus of attention has been popular cinema). These include: firstly, that, the disproportionate anthropological interest in India, and the large number of anthropological films made about Indian, and particularly tribal communities, have frequently failed to disassociate themselves from a colonial viewing-position and perspective. The key problem with such films is that the text functions as a invisibly encoded whole - using conventions at variance from those outlined by Colin MacCabe (1974) in the context of classical realism in Hollywood cinema, but ironically, functioning to the same effect - where the observer/filmmaker captures an endangered, pre-modern, pure cultural 'other', at best, under threat from the ravaging forces of modernisation, and at worst, in idyllic isolation. Secondly, among the various genres of cinema that gained ground in post-independence India, the documentary was most aligned with, and supportive of, a state-driven agenda for several decades. ${ }^{11}$ This meant that the genre became something of a strait-jacketed propaganda format; film form took a backseat to the subject, becoming a medium through which crude government policies were communicated to a captive, albeit grudging audience. But the most crucial reason for the low interest in documentary is the tremendous force exerted by popular Indian cinema (mainly that from Bombay, but also from Chennai) on what one might call the Indian imaginary, and the associated ease for researchers of 'accessing India', or at least parts of it, through the 'Bollywood' cultural idiom.

The key difference is that documentary cinema demands from its audience, a certain locus of believability, distinct from that of melodrama/fiction. 'Believability' is shaped by characteristics of the film text - narrative, editing, characterisation, mise-en-scène and so on - but also by the place occupied by the film's subject ('nation', star, theme) in the spectator's imaginary. And conversely, as some film theorists would have one believe, by the spectator's socio-economic coordinates. I will not rehearse the outlines of the contested 'national history' of Indian cinemas here, but simply allude to the fact that the spectator has been key to theorising Indian cinemas, and also, that the tension between 'nation' and 'state' has shaped much of this discourse. ${ }^{12}$ For example, it is suggested that the 'national 
imaginary' represented by and through popular cinema is at odds with the state's attempt, to instil through its ancillaries (National Film Development Corporation, Films Division, FTII, NFAI), a sense of aesthetic and ideological values through another 'socially sympathetic', 'progressive' or 'parallel' cinema. ${ }^{13}$ The debate between the kinds of audience 'parallel' cinema has catered to, in comparison to the more popular variety has been intensely played out, among other places, in the pages of the film journal Deep Focus. George Kutty, editor of Deep Focus has critiqued the Indian New Wave (which included parallel cinema) for catering to the cultural sensibilities of a middle-class audience which itself was subjugated to a western consciousness. ${ }^{14}$ In a country where details of realism failed to capture the dominant literary imagination (Mukherjee, 1985), Sumita Chakravarty suggests that the general support for cinematic realism in the early post-independence era was linked to 'the intelligentsia's feelings of being alien in their own environment and of their search for a "real" India' (1993: 85). She thereby argues that 'one of the anomalies contained in the demand for realism in cinema is that the concept itself is alien to Indian philosophic and aesthetic traditions. . .but it was taken as a transparent means whereby "Indian reality" could be revealed' (1993: 85). This line of reasoning suggests little hope, or scope, for documentary filmmakers, who by virtue of their chosen genre necessarily engage with a larger social reality, in cultivating an audience. The situation is particularly damning for communities such as the Chharas, for whom survival itself is contingent on dispelling public misperceptions, and contesting representation in the media and cultural sphere. It also seems to elide any openness to inhabiting multiple subject-positions as spectators - any potential movement across audience for popular, parallel, and documentary films - fuelling the myth of 'nationmaking' in terms of texts and audiences neatly categorised as Indian/western, traditional/modern, rural/urban, working-class/middle-class. The reality is that despite the cinematic techniques of closure, film almost always eludes fixity, making the exercise of reading audience through text vacuous. Ironically, in an article titled 'Fragmenting the Nation', Chakravarty quotes Stam and Shohat (1996) in defence of the 'multiaccentual and polyvocal' nature of film, and credits to this fluidity the gap in critical and public readings/ 
responses to Mani Rathnam's Terror Trilogy, thus reinforcing the critical investment in reading film through the framework of nation (2000: 233). The tenacity of such arguments is put to test by examples such as that of Chhara cinema, which, not only represents the subaltern, but is also the product of a subaltern labour and imagination. Let me cite an example of the unpredictability of audience response here: the Madari's, a DNT community that perform as snake-charmers, have lost their means to livelihood since animal rights activists launched a campaign to seize their snakes. Not only this, the activists were so enraged that they put some Madaris into a dog-cage to drive their point home. Bajrange made a short film, Fight for Survival, on this episode to put forward the Madaris' view-point explaining that they did not remove the fangs or venom glands of the snakes, and in fact, did not treat them with cruelty. The film was screened at the Jeevika Film Festival in Delhi (2006) where it won an award. Bajrange also showed it to the Madaris, which he says was a very pathetic and humiliating experience for them. ${ }^{15}$ The interesting episode regarding audiences took place when he showed the film to a group of animal rights activists in Rajkot; following a heated discussion about the future of the Madari community, many activists decided to adopt Madari children and provide them a quality education. Thus, film can sometimes elicit the most unexpected audience response from the least expected quarters. The pleasures and mercies of such fluidity would be wasted and lost if the debate on audiences, genres, and aesthetics is not dislodged from its current ideological home on to a new terrain exploring the material conditions of cinematic production and form in India.

To spell out the implications of such a shift in no uncertain terms, this means that educators and film theorists will need to bear a greater responsibility towards creating spaces within public and academic discourse to find a language for documentary and marginal film cultures. As documentary filmmaker Paromita Vohra wryly states, 'academics and critics develop increasingly sophisticated ways of talking about mainstream culture but a language and framework to assess the contemporary alternative culture seems not to coalesce' (December 2008, Pratilipi). It is telling that there is not a single text available so far that provides an overview of the documentary tradition in India, let alone a comprehensive 
history of Indian documentary. ${ }^{16}$ As has been the case historically in Indian cinema, greater visibility for documentary in the public domain through film journals, festivals, film societies, and the media, should gradually lead to enhancing the culture of documentary viewing and production, a process that has already begun.

\section{$\underline{\text { Cultural Capital }}$}

In contrast to the impoverished condition of critical discourse on documentary is the fact that documentary film production has been thriving over the last two decades, and invoking an articulate sense of the social and political. ${ }^{17}$ This raises an interesting aside on the relationship between theory and praxis in India, as well as that between script and orality in some sense - issues that have long been debated in the field of Indian literature - but that is quite another story. Whatever be the significance of the written word or theory for practice, it is certainly true that an absence of engagement with documentary film leave the theorising of 'Indian cinemas' amiss. However, what this does imply for aspiring documentary filmmakers, is a longer, and perhaps harder struggle to gain access to resources for production, distribution, exhibition and training, independent of a systematic facilitation/ process, which is the second key issue that needs to be addressed in speaking of Chhara filmmakers. It could be argued that those with an interest in films can avail of the NFAl's film appreciation courses, or join the FTII and other private film education institutes that are mushrooming around India: the determined will find a way out, in other words. But in truth, these are beyond the reach of a substantial part of Indian society, and particularly so for DNTs and tribal communities. One, it brings up the issue of literacy, which itself cannot be taken for granted in India; two, it poses the challenge of financial resources to support an education; and three, it raises the vexed question of 'fair' competition for scarce resources (jobs, seats in educational institutes) by historically disadvantaged groups such as the DNTs, Scheduled Tribes (ST), Scheduled Castes (SC) and Other Backward Classes (OBCs). It is no surprise that Bajrange and some of the other Chhara youth learnt filmmaking by experimenting with excess video tapes, leftovers from recording local weddings in the late 
1980s, filmed during the brief half-hours snatched before rented video cameras needed to be returned to their owners. Bajrange narrates:

'I have no godfather in the film industry and neither did I learn filmmaking from any institute. . . As a child I often used to miss school to watch films. I have watched Sholay at least sixty-five times. And I used to wonder how these characters came on the big screen. . . There is a lot of pain, sorrow, problems and stories around me to be able to live life with great enjoyment. . it is my childhood enthusiasm that set me off on this creative journey.' ${ }^{18}$

Eventually he did manage to attend a film appreciation course at the NFAI through the Bhasha Research and Publication Centre, but only after having first made films independently. The double marginalisation of DNTs from the public sphere also means that it is much more difficult to gain access to the financing, distribution and exhibition networks critical to film practice: since DNTs are still refused bank loans and credit cards, financing for independent cinema becomes a very crucial challenge. As modern day bureaucracy involves the writing of lengthy and sophisticated proposals (usually in English) for any funding application, this automatically disadvantages DNTs and other communities whose historical and material circumstances have restricted access to formal education. Besides, stigmatisation as criminals continues to haunt them wherever they go in the film industry: 'there are a few filmmakers in the Chhara community, but due to the stigma, I was never accepted or employed by any producer while I was struggling to get work in the Gujarati film industry. When someone came to know about our identity, immediately they turned their face' ${ }^{19}$ On a sad note, Bajrange mentions that working with Rakesh Sharma on a film about the Gujarat riots in 2002 was an especially harrowing experience, as the police had implicated the Chharas as one of the rioting communities; thus, every time a Muslim interviewee learned of his Chhara identity, their expression and response immediately changed. Rather an unfortunate and deeply saddening episode this, but nothing new to the Chharas, who everyday face persecution by the police, the public, and the state, and have 
done so for centuries. As the only possible entry-genre for emerging filmmakers, particularly those representing marginalised voices, and perhaps those too who do not see an alternative to 'documenting' through film a larger social struggle, and in the context of the challenges and circumstances outlined here, the absence of a critical engagement with documentary on the part of academics and film educators seems not to present an option any longer.

\section{Theorising Chhara/ Marginal Cinema}

How does one then begin to theorise such a marginal cinema as that of the Chharas? And what value would such a theorising offer? To start with, and reverting to Hall's notion of cultural theory cited earlier in the chapter, unravelling the received master narrative about film and media cultures in India, which emphasises a rather distinct role and place for the popular, the folk and the elite (within the 'national'), would expose the myopic vision of such a position. Fortunately or unfortunately, the capacity for artistic cross-fertilisation is higher than everyday human engagement with 'difference' and the 'other'. While exercising caution about the possibility of cultural commodification this creates, art, performance and the media provides a chance to transcend comfort zones, and understand diversity and difference in all its embodied-ness. I will speak through the example of a Chhara film, Bulldozer (2006), which uniquely captures India's contemporary urban predicament, navigating the politics of the production and form of the film, in offering a theoretical reading of Chhara cinema.

In recent years, demolition of residential and commercial property has become a major source of anxiety in less prosperous urban locations in India: a panic that has spread across the country irrespective of the party-politics of regional governments. Bulldozer is a film that addresses this issue by representing the plight of people made 'homeless' through the Ahmedabad Municipal Corporation's 'sanitizing' drive. Positioned as a 'mega-city in the making', the Ahmedabadi middle-classes are in a hurry to dispose off the seeming squalor of 
its underbelly. Many tribal and DNT communities, such as the Sansi, Vaghari, Bairagi, Jogi, and Rajbhoi, who settled down several decades ago in parts of Ahmedabad, particularly in the locality of Maninagar, are now being asked by the Corporation to produce documents that prove their land rights. Papers which, not surprisingly, they don't possess. The film was conceptualised in response to this harassment of such displaced communities; an angry response, when Bajrange found a homeless girl dead on the footpath outside one of India's premier educational institutes, the Indian Institute of Management (IIMA). On watching the film, the spectator learns that several children had succumbed to the cold and died, when the Municipal Corporation broke down their make-shift homes with bulldozers; the homes of some families had been destroyed up to ten times. The youngest child who died was seventeen days old. At the other extreme, two women, one aged 116, the other 106, barely able to sit up, had to be relocated by their families during the demolitions. The interviewees explain that no notice is provided by the Corporation, and no new land is allocated for resettlement; if any opposition is voiced, the police who accompany the demolition squad, use physical force to silence them. Demolitions are particularly savage when dignitaries and political figures are slated to visit the IIMA.

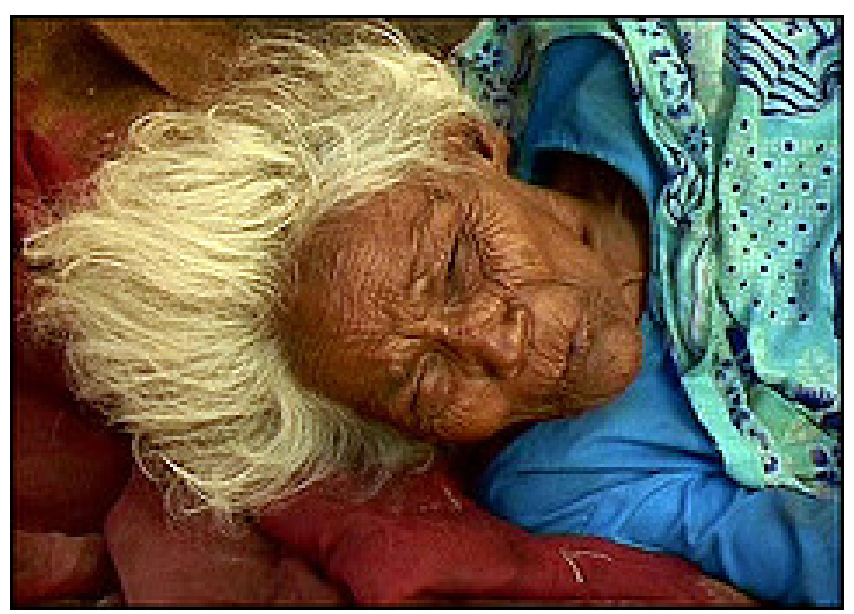

Figure 4. Still from Bulldozer: a 116 year old victim of demolition

Filmed entirely on location, involving a cast which is made up of non-professional actors (and occasionally actors from the Budhan Theatre group), the form of this film represents something between observational cinema (in the vérité tradition) and what 
Solanas and Getino termed as 'interventionist cinema' (Nichols, 1976). Excerpts from interviews reproduced below describe this approach more adequately:

'I started shooting Bulldozer on a handycam, interviewing affected people at IIMA and Maninagar basti. . .different perspectives of the issue emerged as I filmed. . I shot several times. . .there was no specific structure in my mind for this film. . . whenever demolitions occurred I returned to film, sometimes after some days as I didn't want to shoot like news bites. ${ }^{20}$

'I never prepare a script first and shoot accordingly. I always shoot on the spur of the moment, collect the footage keeping the issue in mind and then finally put the entire footage on a time line to make sequences.. . While shooting I just keep the camera rolling most of time because I don't want to lose any momentum. My independent documentary film making style is to catch the moment and that should come out in the film. . I I generally avoid interviews of experts. I don't want the views of experts or my self in the film. It is better that to bring out something one talks with affected people; captures their emotions, thoughts, and problems. According of me that is a true documentary film. ${ }^{21}$

From this description it is clear that many of the conventions of observational cinema the desire to 'capture the moment', long takes and little or no cutting while filming, representing 'voices from below' - are systematically adhered to. Yet, the films also transgress the norms of observation - as observation requires the presence of a literal or symbolic 'other' who can be inscribed in a partial truth (recognising that the kino-eye is always ideological and selective) through filmic revelation - by imposing a structural coherence through extensive editing. ${ }^{22}$ Interestingly, Bajrange does not use sync sound: 'I don't like commentary. Testimonies should speak for themselves, not the director's or researcher's text'. ${ }^{23}$ A problem he highlights in post-production is finding an editor who is sensitive to the issue and the footage; thus he often finds himself sitting with the editor to cut shot by shot. 
The film uses an ensemble approach, juxtaposing stylised shots of daily-use objects, bulldozers, archival footage of activist meetings, interviews, scenes from the Budhan Theatre street play 'Bhoma', interspersed with a voice-over narration of moving prose by Bajrange. Narrativity is constructed episodically by linking socio-political context (symbolised through material objects), testimony/ interview, performance ('Bhoma'), and voice-over in this order. Each episode of the film (not demarcated as an episode) reveals the tremendous influence of the performative on the film's aesthetic. Contrary to the feigned 'transparent' reality of many interview-based documentaries, or the extreme non-interventionist ideals of some observational cinema, Bulldozer (and other Chhara films) accentuates social reality through staged performance. The film's sentiment is fierce, youthful, and resilient, and although reminiscent of Third Cinema as theorized by Solanas and Getino (1976), it moves beyond its emphasis on the 'national', towards a Fourth Cinema (indigenous cinema) that demystifies the myth of the nation as a totality. ${ }^{24}$ Bulldozer forebodes a public outcry against oppressive powers, most poignantly in the concluding scene, an extra-diegetic narration in Hindi superimposed on a frozen still from the play 'Bhoma'.

Loha jab pighalta hai to bhaap nahin uthti

Par kothali uthane wale ke dil se bhaap uthti hai, to loha bhi pighal jata hai

Pighle hue lohe ko kisi bhi aakar mein dhala ja sakta hai

Kothali ki aakar mein is desh ki takdeer dhali hui hai

Aap lohe ki baat karte ho? Hamne loha khaya hai.

'No vapour is generated when iron melts. But the steam generated from the hearts of those picking up the axe melts iron too. Molten iron can be given any shape. The destiny of this nation is shaped as an axe. You talk of iron? We have eaten iron. ${ }^{25}$

It could be argued that the in-between-ness of form (between observation and intervention) is moulded by the filmmakers' and texts' embededness within Chhara history; it is thus, a historiography that writes itself through cinema as opposed to a film historiography 
shaped through textual strategy. And while these films could be interventionist, the films produced so far, seem less concerned with historiography than with history itself.

What Solanas and Getino meant by a cinema that intervenes in history is classically demonstrated by a film such as The Battle of Chile (Guzmán, 1973, Argentina) where considerable pre-production preparation is invested in the analysis of the socio-political situation to shape a script. ${ }^{26}$ Film theorist Ana Lopez argues that such films represent a selfreflexive, analytical cinema, akin to 'historiography in the scripting' (1990: 274). In so far as the writing of the narrative and its form must distil the essence of a historical period/ journey in this kind of interventionist process, it remains distant to Chhara films thus far. The reason for this, I suggest, is that more often than not, historiographical writing (or scripting for cinema) is deployed with the objective of, and to serve the purpose of, rescuing the past and reinstating a un/known version of it. It resembles an inscription of memory: the text/film becoming a receptacle to hold individual and collective utterances of remembrance. The Chhara youth and media producers are working against the grain of history, to distance themselves from the past (not necessarily to forget it, but to move away from its circumstances); the creation of each Chhara film exists as a record of the erasure of the past and present. Each film becomes thus, a receptacle of death, what Susan Sontag (1977) identifies in the photographic record as the 'act of aggression'. As the axis of image production increases, there is a converse decrease in the social historical subject of the image. The act of memorialisation takes place here not within individual film texts, but across and along the range of films, collectively marking a passage of time. Even though the subject matter of each film is different, and in this sense Chhara film production doesn't offer any sort of serialised comment, the films function as a chronicler of time, telling stories of the wider change in Chharanagar and other DNT localities brought about through advocacy, and media cultures over a length of time. Metaphorically speaking, it is a sort of invisible ink, whose writing can be revealed only after the act of writing is complete. 
Rather than draw a conclusion, it seems more appropriate to emphasise that a silent turmoil seems to be brewing in the marginal cultures inhabiting the peripheries of modern India's consciousness; some like the Chharas are expressing this through creative media cultures, others through more aggressive means. Unless the sweeping strokes of South Asian film and media studies are recalibrated away from the 'national' focal point to zero in on the margins, the risk of missing the larger picture runs high. It seems timely thus, to lay down the flags and, as the Chharas say, pick up the axe instead.

\section{NOTES}

' I am grateful to Brian Coates, Alan Grossman, Aine O'Brien, Ganesh Devy and Shakuntala Banaji for their careful reading of the initial draft of this chapter. Their questions, suggestions and critiques have made the process of writing that much more enriching. More so, the residents of Chharanagar, and Dakxin Bajrange in particular, need to be thanked for responding to my incessant correspondence despite the demands of life in Chharanagar.

${ }^{2}$ Mahasveta Devi, tribal rights activist and novelist explains the position of denotified tribes, or DNTs thus: 'In 1871, the British Government of India "notified" certain tribes as "criminals". The logic was simple. These people lived in forests, or were nomads. Only the criminals would do this. As Indians follow caste professions, these mysterious (to the British) people too are hereditary criminals. Thus history's most heinous crime was perpetuated in the 1871 Criminal Tribes Act'. (March 2002, Budhan) ${ }^{3}$ Devy, G.N. (2002) Painted Words, pg.259.

${ }^{4}$ Kasturi, K. (2 Nov 2007) 'Forever Stigmatised: Denotified Tribes', OneWorld. Net (Accessed 20 Jan 2009 at http://archive.oneworld.net/article/view/154795).

${ }^{5}$ Tribal communities in India are commonly referred to as adivasis or janajatis. The term 'tribal' will be used in this essay, as it more easily translates the discourse about de-notified communities.

${ }^{6}$ The Bhasha Research and Publication Centre along with Mahasveta Devi and Lakshman Gaiekwad established a DNT Rights Action Group (DNT-RAG) in 1998 to mobilise denotified communities, and had started publishing a monthly magazine entitled Budhan to keep the members and volunteers of DNT-RAG informed of developments. The story of Budhan Sabar and the Calcutta High Court's ruling 
in this case had been published in the inaugural issue of Budhan (1998); it is also reproduced in Painted Words.

${ }^{7}$ Even though theatre is not a part of the discourse of/on media, in the case of the Chharas, it becomes necessary to treat the emergence of a theatre group as the starting point for exploring the media cultures originating in this area and community. It indicates too, on the one hand, the relative power of theatre as a form of political communication and social activism in comparison to (technologically) mediated forms such as TV, radio, or cinema by way of lower barriers and costs of entry. On the other hand, the groundedness of theatre in the here and now, the attachment of a performance to a locale, necessarily restricts the spread and reach of the theatre, and the possibility of creating an archive or record that can be reinvoked/ re-accessed at another time and place.

${ }^{8}$ Interview with Bajrange, Ahmedabad, 6 January, 2009.

${ }^{9}$ Ibid.

${ }^{10}$ Faleiro, S. (26 November 2005) 'Theives Who Steal A Chance in Life', Tehelka. In addition, Bajrange says, 'the Chharas can never be afraid of the police, they are regarded as friends. . the police collect substantial bribes from Chharanagar, and hence, development of the Chharas undermines the vested interests of the police' (Interview, 6 January 2009).

${ }^{11}$ For an excellent discussion of the role of the Films Division and its documentaries in substantiating the discourse of postcolonial 'nationhood' see 'Moving Pictures: the Films Division of India and the Visual Practices of the Nation-State' in Srirupa Roy's (2007) Beyond Belief: India and the Politics of Postcolonial Nationalism.

${ }^{12}$ For discussions of 'national cinema' see Jyotika Virdi (2003) The Cinematic ImagiNation: Indian Popular Films as Social History; Madhava Prasad (1998) Ideology of the Hindi Film; Sumita Chakravarty (1993) National Identity and Indian Popular Cinema. Also relevant is Valentina Vitali's (2006) critique of Indian film historiography 'Not A Biography of the "Indian Cinema": Historiography and the Question of National Cinema in India'. The 'national' history of Indian cinemas has also been contested in more specific works on regional-language film industries. Moreover, a large part of the New Wave itself did not speak on behalf of the nation as a monolithic entity, and it encompassed films in several different languages. All these discourses do not even begin to take into account the immense documentary production that has taken place in the last two or three decades. 
${ }^{13}$ This argument has been reiterated in various texts on Indian cinema, and possibly most forcefully by Madhava Prasad (1998) in the chapter on 'Developmental Aesthetics' in his book The Ideology of the Hindi Film: A Historical Reconstruction.

${ }^{14}$ See issues 1 (2) June 1988; 4 (2) 1992 of Deep Focus in particular.

${ }^{15}$ Correspondence, 5 April 2009.

${ }^{16}$ The small amount of existing scholarship on Indian documentaries falls within two categories: the first, is the body of material represented by publications like Indian Panorama, listing profiles of IIFT films included in the annual showcase or monographs on documentaries published by the Films Division under the Ministry of Information and Broadcasting; the other are stand-alone essays in books and journals from within the humanities and social sciences framework. For example: Vinay Lal (2005) 'Travails of the Nation' in Third Text; Monteiro and Jayashankar (2001) 'Documentary and Ethnographic Film' in Elsevier Encyclopaedia of Social and Behavioural Sciences; Paromita Vohra (2008)'Knowing for Sure Without Knowing for Certain' in Pratilipi; Surabhi Sharma (2008) 'Songs of the Ship' in Pratilipi; Butler and Mirza (2006) Cinema of Prayoga: Indian Experimental Film and Video; Srirupa Roy's (2007) chapter on the Films Division although very informative, excludes independent documentaries and others not funded by the Films Division; some essays and interviews with documentary filmmakers have been published in Deep Focus too.

${ }^{17}$ Vinay Lal's (2005) 'Travails of a Nation: Some Notes on Indian Documentaries' discusses some documentary films on the theme of communal violence in Gujarat, and provides an optimistic comment on new emerging work in this area. In addition to the filmmakers discussed in Lal's essay (Anand Patwardhan, Suma Josson, Rakesh Sharma and Gopal Menon), several documentary filmmakers including Madhushree Dutta, Paramita Vohra, Sanjay Kak, Anjali Monteiro and KP Jayashankar, Anjali Panjabi, Manjira Datta, Sabe Dewanand Shohini Ghosh have addressed serious, often difficult, socio-political issues through their films.

${ }^{18}$ Correspondence, 5 April, 2009.

${ }^{19} \mathrm{lbid}$

${ }^{20}$ Ibid.

${ }^{21}$ Correspondence, 6 March 2009.

${ }^{22}$ This is a rather simplified view of observational cinema. Lucien Taylor's foreword to MacDougall's (1998) Transcultural Cinema teases out the complexities of observational cinema and its development 
over the years. It is impossible to engage with this material within the scope of this essay, but nonetheless, it is worth pointing out that accessing memory and violating the subject in scenes that the camera-eye cannot be privy to have been identified as serious limitations of observational cinema; docudrama and the autobiographical documentary offer two possible alternatives in redressing this limitation. Hence, once again, it is either the interiority of the speaker-subject (who is positioned as insider/outsider/or both) and fiction, which get called upon to validate the truth element of documentary.

${ }^{23}$ Correspondence, 5 April 2009

${ }^{24}$ See Sawhney, R. (2009) 'Cinema and the Adivasis of India' in Moving Worlds: A Journal of Transcultural Writing, Vol 9, No. 1.

${ }^{25}$ An approximate translation of the Hindi voice-over narration in the film's last scene as used in the subtitles.

${ }^{26}$ In The Battle of Chile, the distance between reality and representation is deliberately collapsed not through an appeal to the viewer to take a leap of faith and believe the pro-filmic frame - by making transparent the scripting of the conflation of reality and its referent. Leonardo Henrickson, the Argentinean cameraman of the film, shoots the scene of his own death, when he refuses to abandon filming at the orders of an army officer, a scene which is also captured by an Equipo cinematographer, and relayed to the spectator in another part of the plot.

\section{REFERENCES}

Butler, B. and Mirza, K., (Ed.) (2006) Cinema of Prayoga: Indian Experimental Film and Video, London: no.w.here.

Chakravarty, S., (2000) 'Fragmenting the Nation: Images of Terrorism in Indian Popular Cinema in Terrorism, Media, Liberation (Ed. Slocham, D.), NJ: Rutgers University Press. Chakravarty, S., (1993) National Identity in Indian Popular Cinema, Austin: University of Texas Press.

Devy, G.N., (2002) Painted Words: An Anthology of Tribal Literature, Delhi: Penguin Books. 
Ellis, J., (2005) 'Documentary and Truth in Television: the Crisis of 1999' in New Challenges for Documentary (Ed. Rosenthal, A. and Corner, J.), Manchester: Manchester University Press.

Kasturi, K., (2 Nov 2007) 'Forever Stigmatised: Denotified Tribes', OneWorld. Net (Accessed 20 Jan 2009 at http://archive.oneworld.net/article/view/154795).

Kutty, G., (June 1988) 'New Cinema: A Legitimisation Crisis?', Deep Focus Vol. 1. No. 2: pp44-49.

Kutty, G., (1992) ‘Popular Indian Cinema: Overcoming Prejudices’, Deep Focus, Vol. 4. No. 2: pp34-43.

Faleiro, S., (26 November 2005) 'Thieves Who Steal A Chance in Life', Tehelka. Available http://www.tehelka.com/story main15.asp?filename=hub112605thieves who.asp.

[Accessed 1 March 2009].

Lal, V., (2005) 'Travails of a Nation: Some Notes on Indian Documentaries', Third Text, Vol. 19. No. 2: pp177-187.

López, A., (1990) 'At the Limits of Documentary. Hypertextual Transformation and the New Latin American Cinema', The Social Documentary in Latin America (Ed. Burton, J.).

Pittsburgh: University of Pittsburgh Press: pp403-432.

MacCabe, C., (1974) 'Realism and the Cinema: Notes on Some Brechtian Theses', Screen, Vol. 15. No. 2: pp7-27.

MacDougall, D., (1998) Transcultural Cinema, New Jersey: Princeton University Press.

Monteiro, A. and Jayashankar, K.P., (2001) ‘Documentary and Ethnographic Film' in Elsevier Encyclopaedia of Social and Behavioural Sciences. 
Mukheerjee, M., (1985) Realism and Reality: The Novel and Society in India, NY; Oxford: OUP.

Nichols, B., (1976) 'The Voice of Documentary' in Movies and Methods, Vol II (Ed. Nichols, B.). Berkeley: University of California Press: pp 258-273.

Prasad, M., (1998) The Ideology of the Hindi Film: A Historical Reconstruction, New Delhi: OUP.

Procter, J., (2004) Stuart Hall: Routledge Critical Thinkers, London: Routledge.

Rabinowitz, P., (1993) 'Wreckage Upon Wreckage: History, Documentary and the Ruins of Memory', History and Theory, Vol. 32. No. 2: pp119-137.

Roy, S., (2007) Beyond Belief: India and the Politics of Postcolonial Nationalism, Durham: Duke University Press.

Sawhney, R., (2009) 'Cinema and the Adivasis of India', Moving Worlds: A Journal of Transcultural Writing, Vol. 9. No. 1. Pp 102-115.

Shah, G., (2004) Social Movements in India: A Review of Literature, New Delhi: Sage Publishers.

Sharma, S., (October 2008) 'Songs of the Ship', Pratilipi. Available http://pratilipi.in/2008/10/songs-of-the-ship-surabhi-sharma/. [Accessed $20^{\text {th }}$ March 09].

Solanas, F. and Getino, O., (1969/1976) 'Towards A Third Cinema' in Movies and Methods: An Anthology, Vol I (Ed. Nichols, B.). Berkeley: University of California Press.

Sontag, S., (1977) On Photography, London: Penguin.

Virdi, J., (2003) The Cinematic ImagiNation: Indian Popular Films as Social Histor, New Jersey: Rutgers University Press. 
Vitali, V., (2006) 'Not A Biography of the "Indian Cinema": Historiography and the Question of National Cinema in India' in Theorising National Cinemas (Eds. Vitali and Willemen). London: BFI.

Vohra, P., (October 2008) 'Knowing for Sure Without Knowing for Certain', Pratilipi. Available http://pratilipi.in/2008/10/knowing-for-sure-without-knowing-for-certain-paromita-vohra/. [Accessed 20 ${ }^{\text {th }}$ March 09]. 